\title{
Pengembangan Buku Ajar Bioteknologi berbasis R-VGT Kelas XI IPA 1 SMAN Senduro Lumajang
}

\author{
Agus Wibisono
}

SMAN Senduro Lumajang, Indonesia

Email: aguswibie@gmail.com

\begin{tabular}{l}
\hline Tersedia Online di \\
\hline http://www.jurnal.unublitar.ac.id/i \\
ndex.php/briliant
\end{tabular}

\begin{tabular}{l}
\hline Sejarah Artikel \\
\hline Diterima pada 27 April 2020 \\
Disetujui pada 18 Mei 2020 \\
Dipublikasikan pada 30 Mei 2020 \\
Hal. 341-347
\end{tabular}

\begin{tabular}{l}
\hline Kata Kunci: \\
\hline Bioteknologi; Mutipresentasi; R- \\
VGT \\
\hline DOI: \\
\hline http://dx.doi.org/10.28926/briliant. \\
v3i4.477
\end{tabular}

\begin{abstract}
Abstrak: Rendahnya prestasi belajar siswa materi Bioteknologi di SMA menjadi tantangan guru biologi, sehingga dituntut mengembangkan bahan ajar. Penelitian pengembangan ini membuat bahan ajar yang kreatif, inovatif, dan komunikatif, untuk mendukung pembelajaran efektif, efisien, dan berkualitas. Materi Bioteknologi relatif baru diajarkan dalam kurikulum SMA, dan rerata nilai Bioteknologi untuk tahun pelajaran 2018/2019 di Kelas XI IPA 1 SMAN Senduro sebesar 62,8 atau kurang dari KKM yaitu 80. Nilai ini melatarbelakangi peneliti untuk mengembangkan buku ajar berbasis R-VGT, yang multirepresentasi, valid, praktis, efektif untuk meningkatkan hasil belajar dan kemampuan berfikir kritis siswa materi Bioteknologi.
\end{abstract}

\section{PENDAHULUAN}

Biologi adalah ilmu tentang gejala alam terkait komponen biotik dan abiotik beserta interaksinya (Warianto, 2011). Pembelajaran Biologi yang diselenggarakan di SMA lebih banyak mengangkat permasalahan dalam kehidupan manusia, dan banyak bersinggungan dengan implikasi-implikasi ilmiah. Hal ini menuntut peserta didik untuk mempelajari dan menguasai ilmu ilmu biologi sebagai salah satu dasar perkembangan ilmu sains (Smarabawa, Arnyana, \& Setiawan, 2013). Pembelajaran saat ini dikembangkan berdasarkan kemajuan sains dan teknologi dimana siswa dituntut untuk mencari sendiri makna dari sebuah ilmu pengetahuan. Pembelajaran di kelas bukan hanya sekedar rutinitas, dimana guru hanya menerangkan materi ajar yang sudah disiapkan dan siswa mendengarkan, tetapi guru dituntut untuk menciptakan suasana pembelajaran yang mampu membuat peserta didiknya sadar untuk mencari dan menemui secara mandiri pengetahuan yang seharusnya mereka kuasai seiring dengan perkembangan teknologi (Sudarsana et al., 2019).

Materi biologi saat ini berkembang terus dan banyak penemuan baru. Ciri khas materi Biologi yaitu berupa fakta, konsep, prinsip dan proses dari gejalagejala hidup, serta seluk beluk yang mempengaruhi hidup termasuk interaksinya dengan lingkungannya (Warianto, 2011). Melihat kondisi tersebut maka diperlukan kreativitas dan inovasi untuk membuat materi biologi menjadi menarik dan mudah dipahami. Pengajaran biologi di sekolah pada umumnya sudah menerapkan banyak model pembelajaran (Endaningsih, 2012; Jagantara, 
Adnyana, \& Widiyanti, 2014; Purnamaningrum, Dwiastuti, Probosari, \& Noviawati, 2012; Susanto, Raharjo, \& Prastiwi, 2012) serta penggunaan modul pembelajaran (Pratiwi, Suwono, \& Handayani, 2014). Perlu diperhatikan bahwa kemampuan belajar siswa dalam belajar biologi tidak hanya dipengaruhi oleh kecerdasan IQ saja namun juga EQ(Daud, 2012). Buku ajar adalah salah satu sarana belajar siswa untuk mempelajari materi biologi, karena dengan buku ajar siswa akan mendapatkan gambaran mengenai isi materi secara baik. Di dalam buku ajar, digunakan tabel untuk memudahkan para penggunanya di dalam memahami maksud dari data yang ada. Tabel digunakan untuk memvisualisasikan data, dan memudahkan pengguna buku ajar membaca dan memahami data, sehingga memengaruhi motivasi dan prestasi belajar siswa. Oleh karena itu maka peneliti mengembangkan sebuah buku ajar yang dikembangkan dan memiliki keunggulan yaitu adanya R-VGT yang mempermudah siswa dalam mencerna materi, terutama pada materi yang bersifat abstrak yakni segala proses yang tidak dapat dilihat secara langsung seperti halnya bioteknologi.

\section{METODE}

Pemecahan Masalah

1. Pendekatan R-VGT dalam pembelajaran adalah pendekatan yang menggunakan beberapa representasi yang di kenal dengan istilah multirepresentasi. Multirepresentasi adalah penggambaran dengan menggunakan lebih dari dua representasi untuk menggambarkan suatu sistem atau proses nyata. Multirepresentasi dapat menggambarkan aspek berbeda dari suatu keadaan nyata atau menggambarkan aspek sama dengan cara yang berbeda

2. Berpikir kritis merupakan kemampuan melakukan evaluasi secara kritis keyakinan, asumsi yang mendasari dan pandangan dunia di mana mereka berada (Aizikovitsh-Udi \& Cheng, 2015; Hafni, 2017; Permana, Hindun, Rofi'ah, \& Azizah, 2019). Ranah kognitifpada tingkatan taksonomi Bloom yang sudah direvisi yaitu pada tingkatan berpikir C4, C5 sampai dengan C6 dari proses berpikir analisis, evaluasi sampai mencipta. Berpikir kritis merupakan metode pengetahuan dari pemikiran, inkuiri logis, dan kecenderungan untuk mempertimbangkan dan menyelesaikan melalui masalah dan subjek dengan pengalaman seseorang(Facione, 2011; Mulnix, 2012). Keterampilan berpikir kritis dapat diorganisasikan, diimplementasikan di ruangan kelas dengan berbagai cara. Guru dapat memilih pengetahuan yang penting dan pengetahuan inti dengan menanamkan keterampilan berpikir kritis ke dalam kurikulum, unit ataupun rencana pembelajaran(Atabaki, Keshtiaray, \& Yarmohammadian, 2015; Klein, 2011; Lau, 2011; Stanovich \& Stanovich, 2010; Yazar Soyad1, 2015).

\section{HASIL}

Implementasi Strategi

Tahap penelitian yang pertama pendefinisian (define), yaitu menganalisis kebutuhan. Kegiatan ini dilakukan kebutuhan guru yang berhubungan dengan pembelajaran dapat diidentifikasi, sehingga diharapkan pelaksanaannya dapat berjalan lebih baik. Analisis kebutuhan dilaksanakan pada dua sekolah di kabupaten Lumajang, yaitu SMAN Senduro. Berdasarkan hasil angket kebutuhan 
$70 \%$ metode guru adalah ceramah dan belum pernah menggunakan buku ajar RVGT, dan pembelajaran secara teacher-centered.

Berdasarkan analisis kurikulum, dalam penelitian ini adalah kurikulum 2013 revisi 2016 (Kementerian Pendidikan dan Kebudayaan, 2013). Kurikulum 2013 berprinsip pembelajaran dilakukan secara interaktif, inspiratif, tidak membosankan, menantang, dapat memotivasi siswa untuk berpastisipasi aktif dan memberikan kebebasan kepada siswa untuk memperoleh kreativitas dan kemandirian sesuai dengan bakat, minat siswa. Beberapa hasil yang diperoleh dari penelitian ini antara lain :

1. Hasil validasi ahli dan pengguna terhadap pengembangan buku ajar berbasis

R - VGT materi bioteknologi pada pembelajaran Biologi untuk siswa SMA dengan rerata nilai validasi ahli oleh dua validator (ahli materi, ahli media dan ahli pengembangan) sebesar 86,06 yang diinterpretasikan dalam kriteria "sangat valid", nilai validasi pengguna oleh 2 guru mata pelajaran Biologi sebesar 85,54 berkriteria "sangat valid". Dari hasil tersebut, buku ajar Bioteknologi berbasis R-VGT valid dipakai di pembelajaran.

2. Hasil uji kepraktisan terhadap pengembangan buku berbasis R-VGT materi bioteknologi pada pembelajaran Biologi untuk siswa SMA mempunyai ratarata penilaian respon siswa yaitu 85,71 meraih kriteria "sangat baik", observasi keterlaksanaan pembelajaran untuk kelas XI IPA 2 berturut- turut sebesar 43,5 meraih kriteria "sangat baik" dan 43 berkriteria "sangat baik", dan C42,5 mencapai kriteria "sangat baik"; uji keterbacaan sebesar 90 dengan kriteria "sangat mudah"; validasi silabus sebesar 86,2 dengan kriteria "sangat praktis". Berdasarkan hasil tersebut, media ajar ini sangatlah praktis dan layak digunakan dalam pembelajaran.

3. Hasil uji keefektifan terhadap pengembangan buku ajar berbasis R-VGT materi bioteknologi pada pembelajaran biologi untuk siswa SMA memiliki kriteria penilaian yaitu penilaian pada bagian kognitif. Pada ranah ini hasil belajar diukur untuk menggambarkan kemampuan dalam berpikir kritis (HOT). Pengukuran hasil belajar untuk kelas XI IPA 2 menunjukkan rerata nilai $\mathrm{N}$-gain pada sebesar 0,31 dengan kategori tergolong sedang. Nilai rataan pre-test sebesar 56,77 sehingga masuk dalam ketegori "rendah", rerata nilai post- test sebesar 81,56 dan dikategorikan dalam "tinggi" dengan peningkatan nilai rata-rata sebesar 22,77. Dan standart deviasi pre-test sebesar 10,76 dan post- test sebesar 7,12. Dapat ditarik kesimpulan bahwa penggunaan buku ajar berbasis R - VGT materi bioteknologi untuk siswa SMA efektif dalam meningkatkan kekritisan berpikir siswa.

\section{PEMBAHASAN}

Pada dasarnya buku ajar merupakan bahan ajar yang sangat penting dan tidak terlepas dari pembelajaran dari level rendah sampai level tinggi(Carolina, Sutanto, \& Suseno, 2017). Ini dikarenakan buku ajar memuat banyak informasi, uraian materi, dan evaluasi (Fendy Hardian Permana, 2015; Pangastuti, Amin, \& Indriwati, 2016). Buku ajar adalah suatu kesatuan unit pembelajaran yang berisi informasi, pembahasan dan evaluasi (Carolina et al., 2017). Buku ajar bioteknologi juga telah dikembangkan (Carolina et al., 2017; Fendy Hardian Permana, 2015; Mauludin, Sukamto, \& Muhardi, 2017; Pangastuti et al., 2016; 
Pratiwi et al., 2014). Pada penelitian ini dikembangkan buku ajar bioteknologi berbasis R-VGT.

Proses pembelajaran dan penilaian diserasikan dengan mengacu kepada standar nasional pendidikan. Semangat yang ada di dalam Kurikulum 2013 berkaitan dengan ranah kognitif adalah meningkatkan kemampuan bernalar siswa, berpikir kritis dan analitis.

Buku ajar ini berisi uraian materi bioteknologi yang runtut, jelas, menarik, dan disusun dengan berbasis R-VGT. R-VGT merupakan media yang dapat membantu pembaca untuk memahami materi ajar secara baik karena akan menampilkan hal abstrak menjadi lebih konkrit. Dengan demikian, buku ajar berbasis R-VGT ini dijabarkan dalam bentuk gambar yang sudah disesuaian dengan ukuran, warna, posisi, bentuk, dan kedudukan secara kompleks, tetapi tetap dalam suatu kesatuan materi yangjelas. Buku ajar berbasis R-VGT ini memiliki beberapa perbedaan dibandingan bukuajar sebelum dan sesudah validasi. Revisi yang dilakukan setelah validasi tidak merubah bagian utama atau bagian terpenting dari materi bioteknologi. Buku ajar berbasis R-VGT ini memiliki beberapa konten yang menarik dan unik untuk mewujudkan tingkat hasil belajar serta kemampuan berpikir kritis siswa. Komponen yang menarik dan unik diantaranya:

1) Buku ini memuat adanya tujuan sehingga akan meningkatkan semangat guru dan siswa dalamproses pembelajaran.

2) Kegiataneksperimenuntuk mengembangkan kemampuan sisa dalam kegiatan praktikum dan siswa akan selalu berusaha untuk memecahkan metode ilmiah.

3) Rangkuman, berisi ringkasan materi yang akan dapat membantu siswa untuk mereview materi.

Untuk perencanaan dan pelaksanaan proses pembelajaran harus disiapkan dengan matang sehingga efisiensi dan efektivitas ketercapaian tujuan pembelajaran meningkat (Sudarsana et al., 2019). Pada kurikulum 2013 revisi 2016 kegiatan pembelajaran harus memberikan ruang kreatif kepada guru dalam memberikan proses pembelajaran dengan mengacu kepada pembelajaran yang bersifat prosedural dan mekanistik (KEMENDIKBUD RI, 2016) . Dari hasil analisis kurikulum tersebut perlu dikembangkan model pembelajaran penyelidikan/pengamatan, agar siswa menjadi lebih aktif dalam kegiatan belajar di kelas.

Analisis siswa bertujuan melihat bagaimana karakteristik dan potensi siswa saat kelas berlangsung. Berdasarkan analisis siswa yang memiliki karakteristik belajar yang heterogen yaitu visual, kinestetik dan auditori maka guru harus kreatif untuk membuat bahan ajar berupa buku ajar yang berbasis multirepresentasi. Guru tidak dapat hanya menggunakan satu buku pegangan saja dalam proses pembelaran, melainkan adanya kreativitas pendidik untuk menciptakan media/bahan ajar (Fendy Hardian Permana, 2015; Mauludin et al., 2017; Pratiwi et al., 2014; Sudarsana et al., 2019).

Evaluasi, berisi pertanyaan dengan soal - soal yang akan dapat digunakan siswa sebagai sarana melatih kemampuan siswa mengerjakan soal agar pemahamannya tentang materi tersebut meningkat. Hal ini pula memberikan kesan positif bagi penulis untuk lebih kreatif dan mencari solusi untuk memberikan pembelajaran yang berinovasi dan merangsang siswa untuk 
melakukan budaya baca, memahamai konsep, dan pembiasaan memecahkan soalsoal level tinggi.

Pada uji kelompok besar, jika ditinjau dari aspek kepraktisan untuk respon guru mendapatkan rerata skor berkategori sangat baik dan untuk keterlaksanaan pembelajaran memperoleh kategori baik dan untuk respon siswa sangat baik. Dari hasil itu ditarik suatu simpulan bahwa buku ajar berbasis R-VGT adalah praktis dan dapat dipakai pada tahap selanjutnya tetapi dengan revisi kecil. Menurut guru dan observer ada beberapa kelebihan dari buku ajar berbasis R-VGT, yaitu dengan adanya kegiatan membaca materi dan menganalisis peremasalahan, siswa menjadi lebih siap dalam melakukan dan menerima materi pada proses pembelajaran. Sedangkan kekurangan dari buku ajar berbasis R-VGT ini adalah membutuhkan waktu pembelajaran yang cukup lama.

Berdasarkan beberapa tahapan penelitian yang telah dilakukan diperoleh produk buku ajar berbasis R-VGT yang valid, praktis, dan efektif serta jika ada perbaikan tetap dilakukan. Apabila dibandingkan dengan buku ajar yang lain, maka buku ajar berbasis R-VGT ini sudah dapat dibuktikan keefektifan dan kepraktisan dalam pembelajaran khususnya pada materi Bioteknologi. Hasil nilai pre test dan post test yang didapatkan memiliki rata-rata di atas Ketentuan Kriteria Minimum. Hal ini menunjukkan bahwa buku ajar berbasis R-VGT meningkatkan kemampuan berpikir kritis.

Jika perbaikan pada tahap ini sudah selesai, maka berlanjut pada tahap penelitian yang terakhir yaitu tahap penyebaran (disseminate), bertujuan untuk menyebarkan produk yang dihasilkan pada sekolah-sekolah lain. Penyebaran dari penelitian ini pada Kelas XI IPA 2 SMAN Senduro. Pada penyebaran ini mendapatkan hasil pada aspek efektivitas dan aspek kepraktisan. Untuk aspek efektivitas pada hasil pre tes dan pos tes, mendapatkan rerata yang termasuk pada kategori sedang. Untuk aspek kepraktisan pada respon guru pada pelaksanaan pembelajaran mendapatkan kategori sangat baik.

\section{KESIMPULAN}

Berdasar pada penelitian yang telah dilakukan, dapat disimpulkan bahwa buku ajar berbasis R-VGT, yang multirepresentasi, valid, praktis, efektif untuk meningkatkan hasil belajar dan kemampuan berfikir kritis siswa materi pelajaran biologi pokok bahasan biotelnologi di kelas XI IPA 2 SMAN Senduro Lumajang.

\section{SARAN}

Setelah melakukan penelitian pada siswa kelas XI IPA 2 SMAN Senduro, peneliti menyampaikan beberapa saran/rekomendasi antara lain untuk guru SMA, buku ajar berbasis R - VGT yang dikembangkan oleh peneliti dapat dijadikan sebagai salah satau alternatif dalam pembelajaran Biologi, khususnya materi bioteknologi. Bagi peneliti lain, diharapkan buku ajar berbasis R - VGT dapat dijadikan referensi untuk melakukan penelitian selanjutnya mengenai pengembangan bahan ajar terutama pengembanan buku ajar R-VGT. 


\section{DAFTAR RUJUKAN}

Aizikovitsh-Udi, E., \& Cheng, D. (2015). Developing Critical Thinking Skills from Dispositions to Abilities: Mathematics Education from Early Childhood to High School. Creative Education, 06(04), 455-462. https://doi.org/10.4236/ce.2015.64045

Atabaki, A. M. S., Keshtiaray, N., \& Yarmohammadian, M. H. (2015). Scrutiny of critical thinking concept. International Education Studies. https://doi.org/10.5539/ies.v8n3p93

Carolina, H. S., Sutanto, A., \& Suseno, N. (2017). Pengembangan Buku Ajar Perubahan Lingkungan Berbasis Model Search, Solve, Create, Share (SSCS) untuk Memperdayakan Kemampuan Berpikir Kritis. Didakti Biologi.

Daud, F. (2012). Pengaruh Kecerdasan Emosional (EQ) Dan Motivasi Belajar Terhadap Hasil Belajar Biologi Siswa SMA 3 Negeri Kota Palopo. Jurnal Pendidikan Dan Pembelajaran Universitas Negeri Malang.

Endaningsih, N. (2012). Peningkatan Hasil Belajar Biologi Dengan Pendekatan Kooperatif Tipe Jigsaw (PTK pada Siswa Kelas XI IPA 1 SMA 97 Jakarta). Formatif. https://doi.org/10.30998/formatif.v2i1.83

Facione, P. a. (2011). Critical Thinking: What It Is and Why It Counts. In Insight assessment. Retrieved from https://www.insightassessment.com/CTResources/Teaching-For-and-About-Critical-Thinking/Critical-ThinkingWhat-It-Is-and-Why-It-Counts/Critical-Thinking-What-It-Is-and-Why-ItCounts-PDF

Fendy Hardian Permana. (2015). Pengembangan Buku Ajar Biologi Berbasis Blended Learning Sebagai Bekal Hidup di Abad 21 untuk Mahasiswa S1 Kimia FMIPA UM. Prosiding Seminar Nasional Pendidikan Biologi 2015, Yang Diselenggarakan Oleh Prodi Pendidikan Biologi FKIP Universitas Muhammadiyah Malang, Tema: "Peran Biologi Dan Pendidikan Biologi Dalam Menyiapkan Generasi Unggul Dan Berdaya Saing Global”, Malang, 21.

Hafni, R. N. (2017). 21st Century Learner: Be A Critical Thinking. The Second of International Conference on Education and Regional Development 2017 (ICERD 2nd), I(1). Retrieved from http://icerd2017.conference.upi.edu/download/

Jagantara, I. W. M., Adnyana, P. B., \& Widiyanti, N. P. (2014). Pengaruh Model Pembelajaran Berbasis Proyek (Project Based Learning) Terhadap Hasil Belajar Biologi Ditinjau Dari Gaya Belajar Siswa SMA. E-Journal Program Pascasarjana Universitas Pendidikan Ganesha Program Studi IPA.

KEMENDIKBUD RI. (2016). Peraturan Menteri Pendidikan Dan Kebudayaan Republik Indonesia nomor 22 tahun 2016. Kemendikbud RI.

Kementerian Pendidikan dan Kebudayaan. (2013). Standar Kompetensi Lulusan Pendidikan Dasar Dan Menengah. Peraturan Menteri Pendidikan Dan Kebudayaan Nomor 54 Tahun 2013. https://doi.org/10.1155/2014/603085

Klein, G. (2011). Critical thoughts about critical thinking. Theoretical Issues in Ergonomics Science. https://doi.org/10.1080/1464536X.2011.564485

Lau, J. Y. F. (2011). An Introduction to Critical Thinking and Creativity: Think More, Think Better. In An Introduction to Critical Thinking and Creativity: Think More, Think Better. https://doi.org/10.1002/9781118033449

Mauludin, R., Sukamto, A. S., \& Muhardi, H. (2017). Penerapan Augmented 
Reality Sebagai Media Pembelajaran Sistem Pencernaan pada Manusia dalam Mata Pelajaran Biologi. Jurnal Edukasi Dan Penelitian Informatika (JEPIN). https://doi.org/10.26418/jp.v3i2.22676

Mulnix, J. W. (2012). Thinking Critically about Critical Thinking. Educational Philosophy and Theory, 44(5), 464-479. https://doi.org/10.1111/j.14695812.2010.00673.x

Pangastuti, A., Amin, M., \& Indriwati, S. E. (2016). Pengembangan Buku Ajar Biologi Sel Dengan Pendekatan Bioinformatika. Jurnal Pendidikan: Teori, Penelitian, Dan Pengembangan. https://doi.org/10.17977/JP.V1I2.6105

Permana, T. I., Hindun, I., Rofi'ah, N. L., \& Azizah, A. S. N. (2019). Critical thinking skills: The academic ability, mastering concepts and analytical skill of undergraduate students. Jurnal Pendidikan Biologi Indonesia, 5(1), 1-8. https://doi.org/10.22219/jpbi.v5i1.7626

Pratiwi, H. E., Suwono, H., \& Handayani, N. (2014). Pengembangan Modul Pembelajaran Biologi Berbasis Hybrid Learning untuk Meningkatkan Kemampuan Berpikir Kritis dan Hasil Belajar Siswa Kelas XI. Jurnalonline. Um. Ac. Id.

Purnamaningrum, A., Dwiastuti, S., Probosari, R. M., \& Noviawati. (2012). Peningkatan Kemampuan Berpikir Kreatif Melalui Problem Based Learning ( Pbl ) Pada Pembelajaran Biologi Siswa Kelas X-10 Sma Negeri 3 Surakarta. Pendidikan Biologi.

Smarabawa, I., Arnyana, I. B., \& Setiawan, I. (2013). Masyarakat Terhadap Pemahaman Konsep Biologi Dan Keterampilan Berpikir Kreatif Siswa Sma. Journal Program Pascasarjana Universitas Pendidikan Ganesha Program Studi IPA.

Stanovich, K. E., \& Stanovich, P. J. (2010). A framework for critical thinking, rational thinking, and intelligence. Innovations in Educational Psychology: Perspectives on Learning, Teaching and Human Development.

Sudarsana, I. K., Nakayanti, A. R., Sapta, A., Haimah, Satria, E., Saddhono, K., ... Mursalin, M. (2019). Technology Application in Education and Learning Process. Journal of Physics: Conference Series. https://doi.org/10.1088/1742-6596/1363/1/012061

Susanto, A., Raharjo, \& Prastiwi, M. S. (2012). Permainan Monopoli sebagai Media Pembelajaran Sub Materi Sel pada Siswa SMA Kelas XI IPA. BioEdu.

Warianto, C. (2011). Biologi Sebagai Ilmu Biologi Sebagai Ilmu. Unair Press.

Yazar Soyad, B. B. (2015). Creative and Critical Thinking Skills in Problembased Learning Environments. Journal of Gifted Education and Creativity. https://doi.org/10.18200/jgedc.2015214253 